\title{
Lens or Prism? How organisations sustain multiple and competing reputations
}

\begin{tabular}{|r|l|}
\hline Journal: & European Journal of Marketing \\
\hline Manuscript ID & EJM-03-2016-0122.R2 \\
\hline Manuscript Type: & Original Article \\
\hline Keywords: & $\begin{array}{l}\text { Corporate reputations, Case Study, Stakeholders, Geographies, } \\
\text { Professional service firms, Prism }\end{array}$ \\
\hline \multicolumn{2}{|l}{} \\
\hline
\end{tabular}




\title{
LENS OR PRISM? HOW ORGANISATIONS SUSTAIN MULTIPLE AND
} COMPETING REPUTATIONS

\begin{abstract}
Purpose (mandatory)

This paper challenges singular definitions, measurements and applications of corporate reputation which tend to be reductionist. We rebuff such narrow representations of reputation by showing the multiplicity of reputation in the case of a global management consulting firm and demonstrate how it has sustained such reputations.

\section{Design/methodology/approach (mandatory)}

Using a large cross-country qualitative case study based on interviews, focus groups, nonparticipant observations, workshops and a fieldwork diary, dimensions of reputation are highlighted by drawing on perceptions from multiple stakeholder groups in different geographies.
\end{abstract}

\section{Findings (mandatory)}

We find significant differences in perceptions of reputation between and within stakeholder groups, with perceptions changing across dimensions and geographies.

\section{Originality/value (mandatory)}

The theoretical implications of the research indicate a plurality of extant reputations, suggesting that a prism is more suited to representing corporate reputation than a singular lens-like focus which is too narrow to constitute reputation. This paper offers theoretical and practical suggestions for how global firms can build and sustain multiple and competing corporate reputations. 


\section{KEY WORDS}

Corporate reputations; Case Study; Stakeholders; Geographies; Professional service firms; Prism

\section{INTRODUCTION}

This paper challenges the narrow, lens-like portrayal of corporate reputation in which companies are depicted as if 'cut from a single cloth' (Fryxell and Wang, 1994; Walker, 2010). This limited focus has been evidenced, for example, in approaches to corporate reputation that seek to define impression-generated, trait-based characteristics under certain finite conditions (Fombrun 1996). We argue that such narrow depictions of corporate reputation may betray deeper prism-like strands shaping the way in which corporate reputations are built and maintained in global business environments, through the multiple stories that emerge from actors who engage relationally with firms.

To explore this issue, we conduct an in-depth qualitative study of a multinational professional service firm. Counter-intuitively, professional service firms may appear unlikely candidates for the study of multiple reputations since they strive to project a single, socially responsible and 'elite' corporate image to clients despite the multifaceted components of their human resource management systems (Empson, 2001). Yet, as extreme cases, this makes them ideal candidates for theorising by seeking to capture how multiple reputations emerge despite efforts towards uniformity across countries, practice groups, and hierarchical organisational levels.

In addressing the research aims, a number of contributions are made to the reputation literature. First, in contrast to prior assumptions in the literature (Fombrun, 1996), we show how different and even competing dimensions of reputation co-exist within a single global 
organisation, which is what we term the prism effect. Second, we demonstrate how these reputations are framed by stakeholder groups and highlight how the plurality of perceptions of organisations across diverse stakeholder groups are sustained. Third, our data indicate contrasting reputations geographically, that is nationally and regionally. Overall, we present an alternative perspective and definition of reputation by revealing its rich prism-like qualities.

\section{THEORETICAL BACKGROUND}

\section{Corporate reputation as a single lens}

Corporate reputation is commonly understood as a stakeholder's overall evaluation of an organisation over time (Abratt and Kleyn (2012: 1050; Gotsi and Wilson, 2001: 29). This evaluation is based on the stakeholder's direct experiences with the company, any form of communication and symbolism that provides information about the firm's actions and/or a comparison with the actions of other leading rivals (Gotsi and Wilson, 2001). In this respect, corporate reputation is seen as an aggregate concept, in which internal and external perceptions combine in a synthetic and singular view of what the organisation represents to others. This can evidently be benchmarked in relation to competitors, who may in turn perceive this as positive, negative or neutral (Walker, 2010). In this view, corporate reputation is not a passing impression about an organisation, but a singular, consistent set of beliefs held by diverse stakeholders - that is, what stakeholders actually think about the organisation (Brown et al., 2006).

The trouble with these definitions is that they overlap with other related but different concepts such as corporate or organisational identity and image (Verčič and Verčič, 2007). Corporate identity (hereafter, "CI") is what the organisation 'is', for example, its intrinsic characteristics, internal attributes, or 'traits' (e.g. strategy, culture, core competencies) that give an 
organisation its specificity, stability and coherence (Cornelissen and Elving, 2003: 115), albeit transmitted through formal and informal communication channels and visual cues by which an audience can recognise the company and distinguish it from others (Kitchen and Schultz, 2001; Kitchen et al., 2013). CI has been primarily used as a marketing tool concerning an organisation's presentation to audiences in favourable ways that serve to enhance external relations and positively influence business outcomes. Accordingly, and for a significant time period, CI has been used interchangeably with visual design, organisational symbol or brandmark (Kiriakidou and Millward, 2000). Demonstrably, though, CI is more than these elements; it is a set of attributes that denotes the ways in which a company operates, behaves and presents itself to diverse stakeholders (Melewar et al., 2003). These attributes encompass the organisation's communication, design, culture, behaviour, structure, industry identity and strategy, which make CI intrinsically related to corporate image (Melewar and Karaosmanoglu, 2006: 864). Thus, CI serves as a connecting linkage between a company and its external stakeholders (Aaker, 2004), and underpins corporate uniqueness and distinctiveness (De Chernatony and Harris, 2000). It is also considered to be a strategic resource for building credibility, awareness and support among stakeholders (Melewar, 2003), and tends to be championed by senior managers (Brown et al., 2006).

Balmer and Greyser (2002: 73-75) sought to disaggregate corporate identity through their $\mathrm{AC}^{2} \mathrm{ID}$ Test framework, which recognised five different types of identity. First, actual identity consists of the current attributes of the corporation; second, communicated identity being the controllable (e.g. advertising) and non-controllable communication (e.g. word-of-mouth) of the organisation; third, conceived identity are the perceptions of internal and external stakeholders; fourth, ideal identity is the optimum position of the organisation in the market at a particular point in time based on research and analysis; and fifth, desired identity is the aspiration and vision of senior managers for the organisation. Balmer and Greyser (2002) note 
that organisations have 'multiple identities', and recognise that each identity type may have nuances depending, for example, on the market and/or the stakeholder group in question. Suvatjis et al. (2012) expand further, identifying not only the multidimensionality of CI, but also the multiple images of organisations among stakeholders.

Despite Blomback and Brunninge's (2009) claim that CI has dominated the marketing literature by focusing on how identity is communicated to external stakeholders, the management and organisational literature has addressed the concept of identity in relation to 'organisational identity' (hereafter, “OI”) (Hatch and Schultz, 1997). OI refers to "a collective shared understanding of an organisation's distinctive values and characteristics" (Hatch and Schultz, 1997:386) with emphasis on how members conceive OI (Stuart, 2002; Verbos et al., 2007). In this context, identity is conceptualised from an (internal) employee perspective through the relationship between staff and their company (Balmer, 2008) which leads to OI being "held in organisation members' minds" (Dutton and Dukerich, 1991:547). OI is expressed by members through shared meaning and belonging (Cornelissen et al., 2007), through an organisation's values, purpose and knowledge based on its history (Gioia et al., 2013) and its everyday behavior and practices (Nag et al., 2007). In broad terms, OI has traditionally had an internal focus on employees which concentrates on how they conceive identity, emphasising what is central, enduring and distinctive to an organisation or its key units of analysis (Albert and Whetten, 1995). This is in contrast to CI which has a more overt external focus that concentrates on how identity is communicated to external customers/stakeholders (Blomback and Brunninge, 2009). From a philosophical stand, OI researchers are concerned with exploring 'who are we?' relative to CI researchers who are concerned with exploring ‘what are we?' (Balmer and Greyser, 2003).

Recently, the organisation theory and marketing perspectives on identity have cross-fertilised each other (Blombäck and Brunninge, 2009), leading to a coalition of the two streams of 
thought. We acknowledge CI as a broad, holistic, multidisciplinary concept incorporating different internal and external elements (Melewar and Karaosmanoglu, 2006). It is considered the sum of all the factors that define and project 'what the organisation is', 'what it stands for', 'what it does', 'how it does it' and 'where it is going' (Melewar, 2003). This is based on the premise that CI is based on OI, which was suggested by Balmer (2001) as the 'ideal' explanation of the relationship between CI and OI.

In relation to image, corporate identity takes an internal/corporate perspective in that it represents what a company believes it is in terms of its strategy, culture, structure and history, which is the basis for communicating its distinctive projected image (Cornelissen et al., 2007), while image refers to the way in which an external party perceives an organisation at a given point in time (Hatch and Schultz, 2002). Image can thus be considered as a snapshot of 'perceived identity' of external stakeholders, while reputation is regarded as the aggregated perceptions developed as internal and external stakeholders receive more information over time about an organisation (Ind, 1997; Abratt and Kleyn, 2012) and is deemed to be more enduring. Although some authors acknowledge the similarities between image and reputation, several distinctions are made. Hawabhay et al. (2009) note that the distinction between corporate image and reputation is based on a historical perspective, that is, the number of years that a company has maintained its survival with consistently favourable behaviour (Fombrun and Van Riel, 1997). Here, reputation is considered in more long-term timeframes than corporate image.

Foreman et al. (2012: 180) argue that reputation stems from OI because the values and behaviours that members display will affect how third parties form reputational judgements. However, Harvey et al. (2016) show in the context of a global management consulting firm that there can be a serious disconnect between the perceptions of senior managers and those of employees and clients, implying a conflict between its identity and reputation which require 
remediation. A similar problem was identified by Balmer and Greyser (2002: 75) who argued that a lack of alignment between any two identities causes dissonance and a potential weakening of the organisation through for example employee disengagement or customer or client dissatisfaction (Cornelissen et al., 2007). In contrast, Verčič and Verčič (2007) found that an organisation's identity and image can be different without necessarily any negative effect on an organisation's financial performance because it can serve varying purposes for different actors.

This suggests that prior work on CI has been overly narrow in viewing corporate reputation as a single aggregation of themes, albeit through multiple criteria. Whetten (1997) argues that the level of agreement among relevant stakeholders surrounding an organisation's reputation is important because it has implications for the strength of the organisation's reputation. Fombrun et al. (2000: 253) developed the Reputation Quotient (RQ), arguing for six main dimensions (emotional appeal, products and services, vision and leadership, workplace environment, social and environmental responsibility, and financial performance) which are perceived differently depending on the stakeholder, hence justifying - perhaps inadvertently the need for understanding perceptions from multiple stakeholders. Walsh and Wiedmann (2004) extended Fombrun et al.'s (2000) work in the same theoretical tradition, suggesting support for the six dimensions, but also found an additional four dimensions in German firms, namely fairness, sympathy, transparency and perceived customer orientation. Schwaiger (2004) further augmented these by suggesting that other dimensions such as fairness towards competitors, while transparency, openness and credibility were also important. Moreover, Barnett et al. (2006) delineated corporate reputation against three different criteria: reputation as a state of awareness, an assessment, and as an asset, while Lange et al. (2011) developed three further important dimensions: 'being known', 'being known for something' and 'generalized favourability'. More recently, Olmedo-Cifuentes et al. (2014) outlined 13 
potential dimensions of reputation, with a further nine dimensions not identified by previous authors (such as business strategy, organisation structure, human resources, organisational culture, ethics, brand image and global reach). Undoubtedly, these themes, criteria, and dimensions could be augmented indefinitely.

However, theoretically, these approaches to corporate reputation draw on the impressionist school in which reputations are constructed through clearly defined, relatively static, traitbased characteristics. We describe these approaches as 'lens-like', taking a metaphor from physics. Lenses focus light by concentrating light spectra into a single image. In the same way, the evaluative and impressional school seek to frame the construction of reputation onto a single, coherent construct. However, given that stakeholder groups can have different perceptions of a firm (Helm 2007), a key question arises as to whether and how firms can sustain many reputations, even when these reputations do not necessarily complement each other in a coherent manner?

\section{METHOD}

\section{Case selection}

To examine this question, we conducted an interview-based study of a large global management consulting firm, titled under the pseudonym, 'Novel Solutions'. This was an appropriate sector to focus on because the management consulting sector has long been regarded as sensitive to issues of business ranking, client regard, and prestige as conferred by others. This consciousness of corporate reputation has given rise to various studies of the networked nature of reputation in the management consulting sector (Glückler and Armbrüster 2003), the way consultants use rhetoric to construct their own reputation (Berglund and Werr, 2000), as well as recognition of the ways 'liminality' may be used to project images of innovation, authority, and legitimacy (Sturdy et al., 2009; Suddaby and 
Greenwood, 2005). Management consulting scholars have given their attention to questions of image and identity in the sector paradoxically, because these elements are difficult to obtain and evaluate given the composite and often temporary nature of the sector in which employees are attracted from diverse quarters (Greenwood et al., 2005; Fombrun, 1996; Rindova et al., 2005).

Second, Novel Insights was an appropriate firm choice as it is one of the leading global management consulting firms striving for elite status among the very top echelons, meaning that a positive reputation across its different functions, stakeholders and geographic locations was crucial. This allowed us to examine how corporate reputations stretched beyond geographical boundaries, both in terms of external client perceptions as well as the location of different regional offices. Existing studies have suggested this as a promising area of research given the limited empirical work to date (Greenwood et al., 1994; Von Nordenflycht, 2010).

\section{Data collection}

In order to assess corporate reputation from the perspective of both internal and external stakeholders, qualitative interviews were conducted with 116 participants across 8 countries (Austria [n=16], China [n=21], Croatia [n=11], Czech Republic $[n=10]$, France $[n=6]$, Germany $[n=33)$, Hungary $[n=2]$ and the UK $[n=17])$. First, internal respondents $(n=56)$ were selected in consultation with an experienced Novel Insights partner and senior consultant based on a range of tenures within the firm: senior (6+ years tenure); middle (4-6 years) and junior (0-3 years) employees. Interviewees ranged from managing partners of country offices to partners, project managers, senior consultants, consultants and internees. Introductions to internal respondents were snowballed in order to achieve a larger sample to avoid selection biases, and validate our findings across a larger population of employees and geographic locations. 
Sampling was carried out with the aim of understanding how perceptions differed across various positions within the firm as well as across geographic regions. There is a lack of empirical multi-country studies within the theoretical literature on corporate reputation and in management research generally (Tsui, 2007). We chose a range of international offices outside of North America as most studies of corporate reputation tend to be US-based. Interviews were conducted in company offices for several days at a time, giving the opportunity for substantial informal non-participant observation and for discussion with individuals and teams when they were in the office.

In addition, we interviewed external stakeholders $(n=60)$, which included clients, non-clients, competitors, and alumni, with some interviewees occupying more than one category. These respondents were identified in consultation with senior members within Novel Insights, and a similar snowball approach was adopted. We requested to speak to external stakeholders with a wide range of relationships with the firm (e.g. long-term and short-term clients, former employees with differing experiences as an employee). We had ongoing face-to-face conversations with key contacts of the firm to ensure that a broad perspective was captured from the internal and external stakeholders we interviewed. We also asked interviewees to recommend people who they thought had similar and different views to themselves of the firm's reputation. We interviewed internal and external stakeholders to respond to concepts in the corporate reputation literature attentive to perceptions gathered from those both inside and outside the organisation (Mahon, 2002; Chun, 2005). All interviews with internal and external stakeholders were conducted in English, with a small number of interviews with external stakeholders requiring a translator.

Interviews were typically conducted face-to-face, although a small number of interviews were conducted over the telephone; and all interviews were recorded and transcribed. Interviewees were asked open-ended questions about their perceptions of Novel Insights as well as closed- 
ended questions about how resultant reputations compared to competitors. Our semistructured interview questions explored perceptions of the firm's reputation internally and externally, through for example probing on perceptions of quality of work, its functional expertise, and factors which made the firm distinctive for different stakeholders and perceptions of the firm's reputation in different geographic regions. We explored and probed particular themes in greater depth depending upon the nature of the interviewee's response to questions. In order to triangulate our findings (Yin 2009), interviews were complemented by four other data sources: non-participant observations, focus groups, one-day partner meetings and a research fieldwork diary. In relation to non-participant observation, the first author was located in several offices for several weeks so that employees and clients could be interviewed and observed. This provided important insights around how the firm sought to position its reputation through the projection of its brand (e.g. via television screens, posters and stationery). Two focus groups were conducted towards the end of the fieldwork with 3 or 4 employees, clients and students, to probe key topics highlighted during interviews that we wished to explore in greater depth with internal and external stakeholders. Three one-day workshops were arranged at the end of the fieldwork with 24 partners from different practice areas in order to understand how Novel Insights managed its reputation as well as to probe further into the findings from interviews and focus groups. From the non-participant observations, focus groups and the one-day meetings, major themes were identified from the prior interviews and the fieldwork diary, and participants were asked open-ended questions related to these themes. This enabled us to examine how concepts of reputation emerged for employees outside of the interview setting. Finally, a fieldwork diary was used to capture some of the informal, spontaneous and often serendipitous observations and discussions, which informed our data analysis and interpretation.

[Table 2 about here] 


\section{Data analysis}

In the first stage of analysis, we developed a rich description of our case setting (Yin, 2009).

We recounted the facets of reputation highlighted by respondents, noting how these varied by demographic, geographic, and hierarchical contexts within the organisation. In the second stage, we used these descriptions to orient ourselves to the raw data, which had been imported into NVivo. Moving between data and the existing literature, we developed a list of first order codes that account for the different perceptions of stakeholders. We relied on the words used by our participants as much as possible. To ensure trustworthiness, an external researcher examined the transcripts for coding as well, and discrepancies were discussed and agreed after talking through in detail the context of particular interviews and focus groups. We then synthesised first order codes into second order themes, which formed the basis for identifying three categories for reputation formulation: dimensions, stakeholders and geography (see Table 2). Dimension referred to the firm's perceived reputation for something, being specific attributes related to how they interfaced with the client market. Stakeholders referred to the firm's perceived reputation with someone, and how these varied from a stakeholder perspective. Finally, geography referred to the firm's perceived reputation in someplace, referring to how physical geography intersected with what firms were known for. These dimensions stemmed from the coding of the data and were labelled by the authors. Preliminary findings were shared with key respondents in follow-up interviews, providing an opportunity for them to respond to the findings and to explore additional themes (Lincoln and Guba, 1985).

We now recount our findings, focusing on our three categories of reputation formulation sequentially. Within each of these categories, we highlight the multiplicity of views thereby illustrating reputation's prism-like qualities in contrast to a lens-like singularity. Data supporting our constructs is included in Table 3 below. 


\section{[Table 3 about here]}

\section{FINDINGS}

\section{Reputation for something (dimensions)}

Employees of Novel Insights expressed different perspectives on the reputation of their firm, sometimes focusing on it being known for providing pragmatic and implementable solutions to clients, but also for lacking creativity during the project delivery stage.

\section{Pragmatic reputation}

A core value that the firm projected to multiple stakeholders was its emphasis on providing practical and realistic solutions to clients. This was reflected through responses that clients provided. A Strategy Director of a global manufacturing company in China, for example, said that she knew the firm "very well" and that the company's strength is "[...] very much results-driven, goal-oriented.” Another Senior Manager of a global manufacturing company in Germany said: "The best reputation they have is in the restructuring field". A Senior Regional Manager of a consumer goods company in Germany agreed that the firm was seen as the:

"[...] more pragmatic consultants out there. So more like okay they say we can save you about, I don't know, 100 million and then after all [sic] the project is done, we have at least a collection of matters summing up that 100 million."

These responses demonstrated a construction of the quality dimension (Lange et al., 2011) which a firm may attempt to project internally and externally. This endeavour to provide clients with customised solutions to their problems is also something that other service firms strive for, with varying degrees of success (Morris and Empson, 1998).

In this case, the firm's external reputation for pragmatism was mirrored internally in another construction of pragmatic reputation. A Principal of Novel Insights in Germany argued:

"But if you really have a problem and if you want to get it solved, regardless of how, regardless of the timeline, regardless of resources, regardless of whatever, then I 
definitely would go for [... Novel Insights]. We've really proved [we are able] to get things done and getting it solved - like in mission-critical projects, you know, projects where other strategy consultants [have been] already proved to fail."

This claim was consistent with responses from other interviewees (see Table 3), that clients perceive Novel Insights as a company that delivers results. A Manager of Novel Insights in Germany said that their clients recognised the firm's ability to provide concrete solutions and results, which had proved important during the global economic crisis when the emphasis has been more on cost-cutting and crisis management rather than blue sky strategy projects:

"So, at the moment, especially now, in the crisis, they tell me 'I really need those operational hands-on guys and don't want to have those brainy [...], a bit more arrogant consultant guys."”

This is an important insight because certain reputation dimensions such as quality can hold different levels of value during particular time periods. During the global financial crisis, the firm's tangible approach secured a lot of work with core clients. Ironically, this was a time when it was also looking to change its reputation from restructuring and cost-cutting to focus more on advising companies on pure strategy projects.

The above constructs are noteworthy since they concur with notions from Lange et al. (2011) and Rindova et al. (2007) that reputation forms as convergence emerges among a broad group of stakeholders and particularly their clients. However, importantly in our data, other narrative constructions of pragmatic reputation emerged which did not subvert the dominant narrative but co-existed alongside it. For example, another positive impression of Novel Insights was that its employees worked closely with the client until the project was completed. A Human Resources Manager of Novel Insights, said:

"I think we are very pragmatic - we don't only develop nice charts and leave our clients alone with this, but we also support them in the implementation phase. We are really people who roll up our sleeves, getting things done. Probably a little bit more down-toearth than the others."

One criticism external stakeholders had of many of Novel Insights' competitors was that they tended to spend short and intensive time periods with clients before leaving them to complete 
the project on their own, often leading to problems. In contrast, one Senior Consultant of Novel Insights in Vienna, argued:

"We don't make some super level strategy that nobody can follow, but more viable and practical strategies."

The two quotations above suggest the importance of reliability in building reputation. The 'super level strategy' references both high profile strategy projects that prominent management consulting firms do and the inability of clients to understand and implement diverse recommendations.

\section{Creativity}

One of the additional perceptions constructed of Novel Insights internally and externally was an apparent weakness in creativity. This seemed to be recognised in the student market with a graduate of a prestigious university for business studies in Germany describing them as " $[\ldots]$ not the most creative." This perception of a lack of creativity seemed to be held by employees at all positions across the company. A junior consultant of Novel Insights in Austria, said for example that the firm: "[...] has a more pragmatic and concrete reputation than an artistic, extremely creative, strategic one.” A Senior Consultant of Novel Insights in Germany agreed that the firm was not known for its strength in strategy:

"Well, probably the most fanciest top-level strategy projects, you know - being very creative, very out-of-the-box thinking. That's probably something [...Novel Insights] is not standing for."

This was noteworthy as it showed how reputations about creativity can coexist alongside reputations of pragmatism. In addition, their reputation about creativity varied across geographies. Despite the perception that Novel Insights lacked creative thinking across different levels of the firm, some offices such as France, for instance, considered their reputation to be strongly creative, which was reflected in their external PR activities and was mirrored with how their clients articulated their expertise in internal surveys. A Principal of 
Novel Insights in France, for instance, argued that his colleagues truly believe in entrepreneurship:

"So I do believe that the entrepreneurship value is differentiating, especially when you compare us to [... three major competitors]."

The implication here is that entrepreneurship is an important dimension of corporate reputation. Another Principal of Novel Insights in France recognized the entrepreneurial spirit of the French office, describing it as "a small boutique" and "dedicated to strategy." This perception in France was at odds with perceptions in other offices in Europe such as the Czech Republic, where a Consultant of Novel Insights, described them as not being as "analytical" or "out-of-the-box thinkers" compared to competitors. These results suggest, as discussed below in the context of China and the UK, geographic variation in the qualities Novel Insights was perceived as being known for.

\section{Reputation with someone (stakeholder)}

Our data reflected perceptions of Novel Insights among internal and external stakeholders and this section focuses on employee perceptions. Responses were stratified into senior (e.g. Partners and Principals), middle (e.g. Senior Consultants and Project Managers) and junior (e.g. Consultants and Internees) employees, and the findings indicate multiple layers of perceptions. Senior members argued that the perception of Novel Insights improved once they started working for the firm, compared to their previous external perceptions. A Principal of Novel Insights in France, said that his perception of the firm beforehand was: “[...] part of those guys who are doing strategic consulting", whereas his impression shifted to seeing it as a "very high-end company" once he started working for them. Another Principal for Novel Insights in France said that external stakeholders had the perception that the firm was "[...] a bit more bread and butter type of work style than maybe other management consultancies", but "[...] usually the clients are then positively surprised once they start working with us." 
Again, the implication is that the impressions of Novel Insights were initially not particularly positive, but they improved as employees and clients became more familiar with the organization. With the first example, the perception of Novel Insights shifted from somewhat prominent when he was just aware of the organisation, to favourability when his impression of its work became positive. With the second example, the perception altered from quality for cost-cutting and restructuring projects ('bread and butter type of work style') to favourability when clients across a range of projects became satisfied with the work. Employees holding middle-level positions also indicated a different perception towards Novel Insights before and while working for the firm. A Senior Consultant for Novel Insights in Eastern Europe admitted that she "[...] wasn't really that much in touch with their work", although she knew they were a "top consultancy" and "highly professional”. She argued: “[...] before I started working for [... Novel Insights] I would say maybe that [... our leading competitor] is number one" and therefore they "deliver higher quality". However, this perception shifted once she started working for the company and she now argues that the firm's leading competitor is not delivering higher quality, but "we are about the same". The use of the term 'we' implies a high level of organisational identification with a perceived alignment between an individual and organizational values and characteristics. Similarly, a Project Manager of Novel Insights in Eastern Europe, "had no clue about" the firm's reputation, although he "knew the other consultancies". However, since he started working for the company, as he noted modestly, it has "[...] increased the reputation a lot, simply by the fact that we are there now".

Among junior employees, the perception of Novel Insights varied geographically. In China, students considered the reputation of the firm as very strong. An internee of Novel Insights in China, described the firm as "prestigious" and a lot of his contemporaries were looking to "pursue a full time position" in the firm. A Consultant of Novel Insights in China admitted that before he started working for the firm, 
"[...] you always have some dream" about working for a "big name" and an "international company", but when you start working for the firm you become more "objective" and "[...] see both the good sides and the bad sides".

These quotations illustrate that students were strongly focused on the strength of the firm's image, as well as its international prowess when they are applying for jobs. However, junior employees were more critical and aware of the firm's core and peripheral strengths for multiple functions once they were working within the firm, which relates to the concept of quality.

\section{Reputation in someplace (geography)}

There has been very little research focusing on whether firms' reputations vary geographically. This is important given the global reach of organisations, including professional service firms such as management consulting firms. This section analyses the reputations of Novel Insights among interviewees in China and the UK. It should be emphasised that this was representative of marked differences in reputations across all eight countries researched in this study. France, for example, was perceived as highly entrepreneurial, whereas Germany was perceived as strong in restructuring and cost-cutting. There is not the space here to analyse all the nuances between countries so we focus on China and the UK in depth to show some of the reputation differences between an Asian and European country and an emerging and established market in management consulting.

\section{China}

Most employees interviewed from Shanghai and Beijing considered both offices collectively when they perceived the firm in China. An HR Manager for Novel Insights in Shanghai, for example, said: "I would not distinguish Shanghai and Beijing, I think I would rather to see them together because they are the China office." A Manager of Novel Insights in Shanghai, agreed: “[...] they don’t care much about Beijing office or Shanghai office. They are just 
treated as the China office.” Importantly, employees emphasised that they were working together rather than benchmarking the reputation of one Chinese office in relation to another. As one Consultant of Novel Insights in Shanghai said:

"We don't compete with each other, and when we have some kind of low time during the project or we have tough clients, we will telephone each other even at midnight and just try to communicate and encourage each other."

This reinforces the collaborative and supportive nature of work conducted between both offices, a finding not necessarily reflected in other global locations. One of the explanations for this collaborative environment between offices is that they are both relatively new and expanding, which required cross-office cooperation in order to strengthen the company's prominence in China. The company has also experienced expansion into other parts of China such as Guangzhou, which has required a lot of support from the more established offices in China.

The impression that many respondents from China gave was that the office had developed very quickly, particularly given the relative infancy of the management consulting sector in China. In addition, employees held positive perceptions in relation to other global offices. One Manager of Novel Insights in Shanghai said that she was "very proud" of the Chinese office which was "number three" within the firm in terms of size and profit and despite the fact that she felt the firm needed to "invest more in China", the offices in Shanghai and Beijing have demonstrated that they are able to "stand on [our] own feet". This response is important because it is clear that they see themselves collectively under the banner of the China office, benchmarked their office's reputation compared to other Novel Insights offices, and also planned for and anticipated expected investment and resources.

Because the management consulting industry is quite new to many clients in China, it was not surprising that interviewees said that Novel Insights tended to focus on smaller-scale projects. A Senior Consultant for Novel Insights in Beijing, described the firm as a "local consulting 
company" despite the industry being "global". To some extent this reflected the scale of the projects not being perceived as significant as their competitors. The vast majority of the employees were also Chinese-born rather than foreign expatriates, which explains in part why many of their clients were Chinese corporations and state-owned enterprises, rather than foreign multinational corporations. One of the consultants for Novel Insights in Shanghai said that he would frequently only communicate with employees and clients in "Mandarin, Shanghainese or even sometimes Beijingese", which reinforces the way in which reputation was built at an office level in China through language. Holding a localised reputation was not necessarily considered negative, as a client, who was the Head of an automotive company in the Asia Pacific, explained:

“[... Novel Insights are] branching into Government, you know, having a lot of Government clients and serving a lot of state-owned enterprises, which is, you know, I think the right thing to do in the China market, because that's where the power, that's where the money, that's where the resources are, and I do believe that, you know, eventually, it's the Chinese companies that's going to take a large share in the Chinese economy."

In other words, the perception of working with local companies could provide Novel Insights with a strategic advantage in terms of access to Chinese clients rather than focusing on foreign multinational clients, although as we discussed above, holding a weaker global image, or lacking prominence, meant the firm missed out on winning large and financially lucrative global projects. The examples above suggest that Novel Insights in China were perceived as holding strong qualities through focusing on local projects with the Chinese Government, but they sometimes missed out on global projects because they lacked prominence and favourability in the region compared to major high profile competitors. 


\section{United Kingdom}

In the United Kingdom (UK), the perception among employees and clients towards Novel Insights was more specialist and lower in profile. One senior manager in the executive search sector in the UK described the company as more 'local' compared to its major competitors:

“[... Novel Insights] is much, much smaller, and it's much more specific as to the sectors it covers. It's more of a niche. The bigger boys [sic], like [name of competitors...], yes, they may have an American parentage, but they are actually much more global, and an awful lot of their consultants are truly international. So local versus global is probably the way I would describe it."

A management consultant working for a major competitor saw the reputation of Novel Insights somewhere between tier one and tier two:

"I think my perception would be that [... Novel Insights] would almost be a firm that sits somewhere between tier one or tier two [...] but they don't command the same name recognition and brand credibility in the UK."

One Senior Manager of the firm in another office described the UK office as the 'Achilles'

heel. A Senior Consultant from the UK admitted that the office was: “[...] probably towards

the bottom in terms of reputation." He went on to argue that he did not feel that the quality of service delivery was any lower than other offices, but that the people in the larger offices:

“[...] feel that those offices are superior to kind of the ancillary markets that don't really $[\ldots]$

have a large presence.” This response suggests more than just competition between offices

related to perceptions of reputation, as intimated by employees working in China, but also

elements of resentment. He went on to argue that when he was working in another

international location for Novel Insights, certain colleagues did not "really care about our

office." A Consultant of Novel Insights in the UK said that the opinion of colleagues in other

offices was that the UK was "[...] slightly more easy going or chilled out office than some of

the other European offices." He also argued that, unlike other offices which had a strong

functional expertise for restructuring, the UK office had employees with a greater diversity of skillsets and therefore "[...] don't do necessarily things the same way that they do". The first quotation showed an office divide of 'us' versus 'them', while the second quotation indicates 
that the expertise in the UK office was more broad-based than other offices that tended to specialise in core areas such as restructuring, implementation and cost-cutting. In both cases, the implication is that perceptions of different global offices varied significantly across countries within the same organisation. This raises questions around the organisation's identity because there is a dissonance between the global values of the organisation and the perceptions of these values among employees in the UK office. This shows how organisations can attempt to create a global organisational identity through emphasising certain core values, but this can manifest itself in very different ways across offices. There was also reliance on larger offices for importing expertise. A Senior Consultant of Novel Insights in the UK said that most of the big projects that the office had won had been a result of harnessing the expertise and contacts of partners in other global locations and "It's only the smaller projects that come through the UK partners." This builds on the work of Wilson (1983) who found that firms often attempt to build their credibility through 'renting' the reputations of outside auditors. We found that individual offices were 'borrowing' expertise from within the organisation in order to build their reputation. In some cases, the borrowing not only existed in the short term for procurement bids and delivering client projects, but more long-term partner transfers to move functional expertise from one market to another. This was also a strategy used to build the reputation of the Chinese offices through deploying a highly successful European partner to head the company's Asia-Pacific operations.

The firm was known in the UK, but not seen as having a particularly high profile or favourable light compared to some other high profile offices. The perception of the UK office of Novel Insights also depended on the stakeholder. A Partner of Novel Insights in the UK admitted that the perception was divided. On the one hand, the perception was "non-existing" with potential clients, who would say “[...] Novel Insights, who?” because they had not heard 
of the firm. He said that when he moved to the UK from another office, it took him some time to adjust to the fact that the company's prominence was much lower:

"But when I came over, it took me six months I think for the first project I got, which was then a large one, which was good, but I thought like there's something wrong here, but I had to change the mindset of people."

On the other hand, clients who have worked with the firm in the UK have tended to be very satisfied: "If people know us and have worked with us, there is a strong reputation, so we also have a lot of repeat clients." The above example from a partner implies that the UK office was not even known among many potential clients in the UK, but clients who had worked with the UK office were generally very satisfied with their work, which suggests that favourability is built from the accumulation of positive client experiences and loyalty over time in relation to their prior expectations.

\section{DISCUSSION}

Building on prior work on corporate reputations (Davies and Chun, 2002; Wartick, 2002;

Davies et al., 2004; Helm, 2007), this paper highlights the way in which multiple reputations can coexist in a single organisation, even when they are not only diverse but even possibly conflicting. The findings challenge other narrow, lens-like understandings of corporate reputation in the literature by showing how the multiplicity of reputations emerge as employees and external stakeholders 'use' stories, vignettes, and labels from their personalised interactions with the firm to construct stories about corporate reputation. These tend to show that reputation is not a singular concept strengthened, for example, through consistency, as has been implied by certain rankings such as Fortune's Most Admired Companies (FMAC) which take a narrow and reductionist interpretation of reputation, but rather reputation is something that emerges as relational ties get articulated and strengthened through personal experience. Figure 1 represents a conceptual depiction of our argument. The 
left-hand side of the prism represents sources of reputation for an organisation, such as the organisation's performance (something), its activities (someone), and geographical context (someplace). The right hand side of the prism represents multiple, diverse perceptions of the organisation, which are salient for different internal and external stakeholders. These reputations are depicted as spectra from a prism, and are therefore not overlapping but rather constituted from the relationship between the individual and the organisation.

[Figure 1 about here]

Taken together, we now explain how our findings and conceptual model extend existing theory and literature on corporate reputation in at least three ways.

\section{Multi-faceted reputations within a category}

The first contribution from the data showed how actors initially constructed a set of labels for the firm as being 'pragmatic', 'down-to-earth' and providing 'implementable' solutions for clients. Adopting a trait-based perspective to reputation is not surprising since many professional service firms seek this reputation (Morris and Empson, 1998) especially for their service quality (Walsh and Beatty, 2007). Yet our data revealed that even as the firm developed this reputation, it simultaneously had a conflicting reputation related to its creativity capability. Our interest here was not whether this reputation was 'good' or 'bad' per se, but whether these diverse interpretations or 'slants' of reputation could co-exist without rendering the initial reputation (of pragmatism) void. This ability to sustain multiple, competing slants is what we intend to invoke through the prism metaphor (see Figure 1).

Whereas a lens concentrates light into an image, prisms refract light into multiple spectra that are equally valid but mutually exclusive. This multiplicity is sustainable because of the physical relationship between the light beam and the prism that enables each spectrum to be a self-contained whole. In the same way, our findings show how organisations can sustain 
multiple reputations that may be diverse and even contradictory, but are sustained through the relationship the respondent has with the firm. In doing so, we challenge a common assumption in much of the reputation literature that consensus or validation of shared experiences is central to reputation.

Prior studies on corporate reputation have recognized that multiple stakeholders can construct reputations (e.g. Walsh and Beatty 2007). However, our findings take this further by showing how the divergence between these multiple reputations is sustained. Specifically, an important mechanism in our findings is the relational ties that individuals form with firms at the exclusion of others. Thus, reputation is not collectively negotiated but is individually constructed and sustained. This is important as it suggests that negative reputations among some stakeholders need not always be managed if other stakeholder groups who are more salient for the organisation form different, positive meaning constructions. Therefore, whilst some scholars have talked about the inertness of reputation or its 'reputational stickiness' (Greenwood et al., 2005), our findings suggest that this may not be problematic. Rather than amend their reputation, organisations may simply be able to form different ones as they attract new important stakeholders interacting with their products and/or services (Olmedo-Cifuentes et al., 2014).

\section{Multi-faceted reputations across categories}

A second contribution of the paper is to show how multiple narrative constructions can coexist within a single reputational category (such as a dimension) and we demonstrate how multiple reputations can emerge between categories. For example, we show how Novel Insights sustained different reputations based on stakeholders and geographies. With variation by stakeholder, our findings highlighted differences between internal and external actors; while our findings on geography showed that the same firm could sustain different reputations in the UK and China without perceptual contradictions emerging. This is important as it 
extends existing definitions of reputation and shows how conflicting narratives can be managed. The existing literature assumes that the decision by firms to pursue multiple products and services to clients at the local level can add risk by creating too much variation and ambiguity about a firm's core competencies across geographic markets. Our findings suggest a modification to this notion. In terms of stakeholders, for example, our data showed at a surface level that the distinct differences within and between stakeholder groups were sustainable. Thus, rather than adopting a singularly narrow definition of reputation among a finite group of stakeholders (Carter and Deephouse, 1999), we suggest this lens-like approach may be insufficient to explore all the nuances of corporate reputation and it is problematic to term this as reputation because it is reductionist in its representation and scope. Instead, we propose a prism-like approach to reputation that incorporates multiple, diverse and sustained perceptions of an organisation, which are salient for different internal and external stakeholders and mutually exclusive. These are based on significant and varied relationships and experiences of stakeholders with the organisation (see Table 1).

At a more fine-grained level, we found marked differences in the reputation of the firm among employees when they were asked to reflect on their perceptions of the firm before they started working as employees (external stakeholders) compared to their perceptions at the time of the fieldwork when they were employed in the organisation (internal stakeholders), which suggest misalignment between actual and conceived identities (Balmer and Greyser, 2002). In all cases, the reputation became less superficial as employees became aware of the firm's core values and expertise as well as its weaknesses compared to its competitors. This is important theoretically because existing literature tends to theorise reputation at an organisational level, rather than at the individual level (Fombrun and Gardberg, 2000; Walsh et al., 2009; Ali et al., 2015). By changing the level of analysis, our findings show that an individual's regard for the organisation's reputation may strengthen as time passes, thereby 
allowing them to construct a reputation through their individualised relationship with the firm and their own direct experience (Gotsi and Wilson, 2001).

\section{Geography and corporate reputation}

Our third contribution is to bring a geographic focus to corporate reputation. Our findings suggest that internal and external actors can come to different understandings of corporate reputation in various geographic contexts or form competing views of the organisation, yet demonstrably these can still satisfy the requirements for 'corporate reputation'. For example, the Chinese office of Novel Insights was considered as a 'rising star' and 'number three' within the organisation, whereas the UK office was seen as one of the firm's 'Achilles heels' and near the bottom of the organisation's office hierarchy in terms of reputation. This is a significant insight because these findings go beyond the argument elsewhere in the literature that geographical context is important to study and affects stakeholder perceptions of companies (Bartikowksi et al., 2011; Soleimani et al., 2014; Ali et a., 2015). We extend this literature not only showing how the reputation of an organisational partnership varies both internally and externally by geography, but also why: namely, because of the distinct relationship that the individual has with the organisation. For instance, while there were marked differences in perceptions that employees had of the Chinese offices compared to the UK offices, there were also nuances within these countries. In China, for example, the Shanghai and Beijing offices worked very closely with each other and considered both offices as one 'China' office, whereas other Chinese offices such as Hong Kong was structured under China within the firm, but they were perceived as somewhat distinct from the Shanghai and Beijing offices. We draw on Walker's (2010: 369) notion of the 'issue specific' nature of reputation - that is, the focus of different stakeholders is predicated upon criteria embedded in a country - and extend this to the issues facing individuals within the organisation. In our study, we were able to examine variations between multiple offices within a country. In the 
case of our China study, for example, some although not all of employees in these offices tended towards a uniform reputation of the organisation. This is important since it shows that the narrative constructions that underpin multi-reputations are not limited to an organisation's competitive positions within a geographic market, but are attenuated to the local context of interpreters. Thus, while reputation might stem from common narratives within the macrostructure, this need not be regarded deterministically but is rather particular to the perspectives and interpretations of individual reputational judgements. Empirically, our study also extends the geographical variety and reach with which corporate reputation has been examined to date.

\section{LIMITATIONS AND CONCLUSIONS}

Our argument challenges assumptions in the corporate reputation literature and in management practice that centre on singular reputation for organisations. While we recognise the intuitive appeal for marketing and public relations of this assumption, as has been evidenced by the explosion of league tables, ratings and rankings, we also wish to highlight some of the complexities that this approach masks. One issue alluded to but not pursued further in this paper is the extent to which certain issues are more important in framing corporate reputation than others. A suggestion in our findings was that 'quality' served as a relatively important driver for corporate reputation, especially during the global financial crisis. However, it is not clear why this issue might prove more important than other issues, such as discounting, ethical service, or historical performance. This attends to a broader conceptual question about the interdependences between related concepts in the reputation literature such as prominence, favourability and quality (Lange et al., 2011; Rindova et al., $2005,2007)$. Further research is needed to understand why certain issues are important, and how individual level variation relates to reputation as an organisational-level construct. 
Empirically, this may mean that future studies examine a broader group of stakeholders beyond customers, shareholders and employees.

Second, we have a limited understanding about how reputation influences labour market mobility. For example, employees join (and leave) firms due to their intangible value and corporate reputational advantage (Harvey and Morris, 2012). Our findings show that certain offices imported labour while other offices exported partner expertise as a means of redistributing their reputation between offices. This implies that certain prestigious offices and celebrity actors have a disproportionate ability to build reputations. Again, our evidence is limited to a single large qualitative study, but future contributions may examine the literature on celebrity firms and celebrity CEOs (see Hayward et al., 2004; Wade et al., 2006; Rindova et al., 2006; Pfarrer et al., 2010), as well as cross-boundary knowledge flows (Tortoriello and Krackhardt, 2010). At issue here is when, how and why corporate reputations influence labour mobility as a way of quantifying the intangible 'value' associated with reputational benefits.

Finally, the data indicate perceptions change over time among employees. However, richer longitudinal research is needed to explore what internal and external factors drive reputation to change over time, both from the perspective of internal and external stakeholders. For example, it is not clear what the interplay is between internal and external stakeholders as well as between intermediary actors who sit on the fringes of the two groups such as investors, clients and alumni. In other words, how far may reputations change externally to internally (e.g. from outsiders to employees) and internally to externally (e.g. from employees to outsiders)? Herein lies a limitation with the generalisability of our findings and while we seek to make a conceptual contribution to concepts in the corporate reputation literature using rich qualitative data, we are aware than these findings need to be complemented by larger, 
quantitative datasets, such as FMAC, the RepTrak ${ }^{\mathrm{TM}}$ Pulse and other valuable surveys of corporate reputation.

\section{MANAGERIAL RELEVANCE}

Our research has shown that corporate reputation may vary markedly depending on the corporation, dimensions, stakeholder and geography in question. First, with dimensions we found that the firm sometimes made claims about expertise (e.g. creativity), which employees and clients did not believe in. This highlights the importance of ensuring alignment between a firm's corporate identity (how it presents itself, particularly from the perspective of senior managers) and its reputation (how internal and external stakeholders perceive it). Any significant dissonance between CI and reputation will ultimately lack credibility among different groups. Therefore, CI needs to be created both top-down and bottom-up, with regular identity reviews to ensure alignment.

Second, we found that the reputation of the subject organisation was significantly different when individuals were external stakeholders, either potential employees or alumni, compared to when they were employees. This suggests that organisations need to recognise that their reputations may be different among stakeholders and they should tailor their communication programmes to these groups. One managerial implication of this is that senior executives may be best placed to create and preserve corporate reputation through early engagement with staff, rather than focusing only on organisational-level activities. Employees, for example, have the ability to engage with both potential and former employees and therefore should be deployed strategically for managing the firm's reputation among these different stakeholders.

Third, our results show how the distribution of talent between offices can help to build reputation in new markets and align reputation between offices. The managerial challenge, however, is ensuring uniformity and avoiding asymmetrical standards across geographic 
locations as this creates tensions between offices and sends mixed signals to external stakeholders about the firm's reputation. This does not necessarily mean that the firm's reputation is the same across geographic markets, but it does mean that there is consistency in the quality of products and services offered and how they are perceived. We argue that this is likely to be particularly salient for organisations seeking to build their reputations and achieve an elite status when expectations among internal and external stakeholders are markedly higher compared to less reputable organisations.

Finally, corporate reputation is a more composite construct than hitherto portrayed in the literature. It has been described as a 'meta-construct' that emphasises the perceptions of various stakeholders (Lange et al., 2011). Extending this concept to incorporate multiple reputations means that organisations need to do more than build and position their reputations in relation to their competitors (Fombrun, 1996, 2012), but also relative to other internal offices, departments and practice areas within global organisations because internal unevenness in reputation seems to signal externally reputational asymmetry. Given this, there is a danger of relying exclusively on popular annual surveys in making reputational judgments. Although such surveys are valuable for providing a broad overview, it is important to understand the limitations such as their emphasis on the perceptions of a particular stakeholder group, or on a certain geographic location, as well as the methods used to collect data.

\section{REFERENCES}

Abratt, R. and Kleyn, N. (2012). Corporate identity, corporate branding and corporate reputations: Reconciliation and integration. European Journal of Marketing, 46(7/8): 10481063.

Albert, S. and Whetten, D. (1985). Organizational Identity. In Organizational Behavior. JAI Press, Greenwich, CT, pp. 263-295. 
Ali, R., Lynch, R. and Melewar, T.C. (2015). The moderating influences on the relationship of corporate reputation with its antecedents and consequences: a meta-analytic review. Journal of Business Research, 68(5): 1105-1117.

Anand, N., Gardner, H.K. and Morris, T. (2007). Knowledge-Based Innovation: Emergence and Embedding of New Practice Areas in Management Consulting Firms. Academy of Management Review, 50(2): pp. 406-428.

Balmer, J.M. (2001). Corporate identity, corporate branding and corporate marketingseeing through the fog. European Journal of Marketing, 35(3/4): 248-291.

Balmer, J.M. and Greyser, S.A. (2002). Managing the Multiple Identities of the Corporation. California Management Review, 44(3): 72-86.

Balmer, J.M. and Greyser, S.A. (2006). Corporate marketing: integrating corporate identity, corporate branding, corporate communications, corporate image and corporate reputation. European Journal of Marketing, 40(7/8), 730-741.

Balmer, J.M. (2008). Identity based views of the corporation: Insights from corporate identity, organisational identity, social identity, visual identity, corporate brand identity and corporate image. European Journal of Marketing, 42(9/10): 879-906.

Barnett, M.L., Jermier, J.M. and Lafferty, B.A. (2006). Corporate reputation: The definitional landscape. Corporate Reputation Review, 9(1): 26-38.

Bartikowski, B., Walsh, G., \& Beatty, S. E. (2011). Culture and age as moderators in the corporate reputation and loyalty relationship. Journal of Business Research, 64(9): 966972.

Berglund, J. and Werr, A. (2000). The invincible character of management consulting rhetoric: How one blends incommensurates while keeping them apart. Organization, 7(4): 633-655.

Bernstein, D. (1984). Company Image and Reality: A Critique of Corporate Communications. Holt, Rinehart and Winston, The Advertising Association, Eastbourne.

Blombäck, A. and Brunninge, O. (2009). Corporate identity manifested through historical references, Corporate Communications: An International Journal, 14(4): 404-419.

Bromley, D.B. (1993). Reputation, Image and Impression Management. Chichester: John Wiley \& Sons. 
Brown, B. and Perry, S. (1994). Removing the financial performance halo from Fortune's “Most Admired” companies. Academy of Management Journal, 37(5): 1347-1359.

Brown, T.J., Dacin, P.A., Pratt, M.G. and Whetten, D.A. (2006). Identity, Intended Image, Construed Image, and Reputation: An Interdisciplinary Framework and Suggested Terminology. Journal of Academy of Marketing Science, 34(2): 99-106.

Carter, S.M. and Deephouse, D.L. (1999). Tough talk and soothing speech: managing reputations for being tough and for being good. Corporate Reputation Review, 2(4), 308-332.

Chun, R. (2005). Corporate reputation: Meaning and Measurement. International Journal of Management Reviews, 7(2): 91-109.

Cornelissen, J.P., Haslam, S.A. and Balmer, J.M.T (2007). Social Identity, Organizational Identity and Corporate Identity: Towards an Integrated Understanding of Processes, Patternings and Products. British Journal of Management, 18: S1-S16.

Davies, G. and Chun, R. (2002). Gaps between the internal and external perceptions of the corporate brand. Corporate Reputation Review, 5(2-3): 144-158.

Davies, G., Chun, R., Vinhas da Silva, R. and Roper, S. (2004). A Corporate Character Scale to Assess Employee and Customer Views of Organization Reputation. Corporate Reputation Review, 7(2): 125-146.

De Chernatony, L., Harris, F. and Dall'Olmo Riley, F. (2000). Added value: its nature, roles and sustainability. European Journal of Marketing, 34(1/2): 39-56.

Donaldson, T. and Preston, L.E. (1995). The stakeholder theory of the corporation: Concepts, evidence, and implications. Academy of Management Review, 20(1): 65-91.

Dutton, J.E. and Dukerich, J.M. (1991) Keeping an eye on the mirror: Image and identity in organizational adaptation, Academy of Management Journal, 34 (3): 517-554.

Empson, L. (2001), Fear of exploitation and fear of contamination: Impediments to knowledge transfer in mergers between professional service firms. Human Relations, 54(7): $839-862$.

Fang, L. H. (2005), 'Investment Bank Reputation and the Price and Quality of Underwriting Services.' The Journal of Finance, 60(6): 2729-2761.

Ferguson, P.D., Deephouse, D.L. and Ferguson, W.L. (2000) 'Do strategic groups differ in reputation?', Strategic Management Journal, 21(12): 1105-1215. 
Fombrun, C.J. and Shanley, M. (1990). What's in a name? Reputation building and corporate strategy. Academy of Management Journal, 33(2): 233-258.

Fombrun, C.J. (1996). Reputation. Realizing Value from the Corporate Image. Boston, Massachusetts: Harvard Business School Press.

Fombrun, C.J. and Van Riel, C. (1997). The Reputational Landscape. Corporate Reputation Review, 1(1/2): 5-13.

Fombrun, C.J. Gardberg, N.A. and Sever, J.M. (2000). The reputation quotient: A multi-stakeholder measure of corporate reputation. Journal of Brand Management, 7(4): 241255.

Fombrun, C.J. (2012). The building blocks of corporate reputation: definitions, antecedents, consequences. In The Oxford Handbook of Corporate Reputation (Eds. Barnett, M.L. and Pollock, T.G.), 94-113.

Foreman, P.O., Whetten, D.A. and Mackey, A. (2012) An identity-based view of reputation, image, and legitimacy: Clarifications and distinctions among related constructs. In: Barnett ML and Pollock TG (eds) The Oxford Handbook of Corporate Reputation. Oxford: Oxford University Press, 179-200.

Fryxell, G.E. and Wang, J. (1994). The Fortune Corporate 'Reputation' Index: Reputation for What? Journal of Management, 20(1), 1-14.

Gioia, D.A., Patvardhan, S.D., Hamilton, A.L. and Corley, K.G. (2013). Organizational identity formation and change. Academy of Management Annals, 7(1): 123193.

Glückler, J., and Armbrüster, T. (2003). Bridging uncertainty in management consulting: The mechanisms of trust and networked reputation. Organization Studies, 24(2): 269-297.

Gotsi, M. and Wilson, A.M. (2001) 'Corporate reputation: seeking a definition.' Corporate Communications: An International Journal, 6(1): 24-30.

Greenwood, R., Hinings, C.R. and Brown, J. (1994). 'Merging Professional Service Firms.' Organization Science, 5(2): 239-257. 
Greenwood, R., Li, S. X., Prakesh, R. and Deephouse. D. L. (2005). 'Reputation, Diversification, and Organizational Explanations of Performance in Professional Service Firms.' Organization Science, 16(6): 661-673.

Harvey, W.S. and Morris, T. (2012). A labor of love? Understanding reputation formation within the labour market. In Barnett, M.L. and Pollock, T.G. (eds.) The Oxford Handbook of Corporate Reputation. Oxford University Press, Oxford, 341-360.

Harvey, W.S., Morris, T. and Müller Santos, M. (2016). Reputation and identity conflict in management consulting. Human Relations [Online First].

Hatch, M.J. and Schultz, M. (1997) Relations between organisational culture, identity and image. European Journal of Marketing, 31(5): 356-65.

Hatch, M.J. and Schultz, M. (2002). The dynamics of organizational identity. Human Relations, 55(8): 989-1018.

Hayward, M.L., Rindova, V.P., and Pollock, T.G. (2004). Believing one's own press: The causes and consequences of CEO celebrity. Strategic Management Journal, 25(7): 637653.

Hawabhay, B.B., Abratt, R. and Peters, M. (2009). The role of corporate communications in developing a corporate brand image and reputation in Mauritius. Corporate Reputation Review, 12(1): 3-20.

Helm, S. (2007). 'One reputation or many? Comparing stakeholders' perceptions of corporate reputation.' Corporate Communications: An International Journal, 12(3): 238-254.

Ind, N. (1997). The Corporate Brand. Basingstoke: Palgrave Macmillan.

Kitchen, P.J. and Schultz, D.E. Eds (2001). Raising the Corporate Umbrella, Basingstoke: Palgrave Macmillan.

Kitchen, P. J., Tourky, M., Dean, D., and Shaalan, A. S. (2013). 'Corporate Identity Antecedents and Components: Toward a Theoretical Framework'. Corporate Reputation Review, 16(4): 263-284.

Kiriakidou, O. and Millward, L. J. (2000). Corporate identity: external reality or internal fit? Corporate Communications: An International Journal, 5(1): 49-58.

Lange, D., Lee, P. M., and Dai, Y. (2011). 'Organizational Reputation: A Review', Journal of Management, 37(1): 153-185. 
Lincoln, Y.S. and Guba, E.G. (1985) Naturalistic Inquiry. Sage, Beverly Hills, CA.

Mahon, J.F. (2002). 'Corporate reputation research agenda using strategy and stakeholder literature', Business \& Society, 41(4): 415-445.

Melewar, T.C. (2003). Determinants of the corporate identity construct: a review of the literature. Journal of Marketing Communications, 9(4): 195-220.

Melewar, T.C. and Karaosmanoglu, E. (2006). Seven dimensions of corporate identity: A categorisation from the practitioners' perspectives. European Journal of Marketing, 40(7/8): 846-869.

Morris, T. and Empson, L. (1998). Organisation and expertise: An exploration of knowledge bases and the management of accounting and consulting firms. Accounting, Organizations and Society, 23(5): 609-624.

Nag, R., Corley, K.G. and Gioia, D.A. (2007). The intersection of organizational identity, knowledge, and practice: Attempting strategic change via knowledge grafting. Academy of Management Journal, 50(4): 821-847.

Olmedo-Cifuentes, I., Martínez-León, I. M. and Davies, G. (2014). Managing internal stakeholders' views of corporate reputation. Service Business, 8(1): 83-111.

Pfarrer, M.D., Pollock, T.G. and Rindova, V.P. (2010). A tale of two assets: the effects of firm reputation and celebrity on earnings surprises and investors' reactions. Academy of Management Journal, 53(5): 1131-1152.

Rindova, V.P., Williamson, I.O. Petkova, A. P. and Sever, J. M. (2005). Being Good or Being Known: An Empirical Examination of the Dimensions, Antecedents, and Consequences of Organizational Reputation. Academy of Management Journal, 48(6): 1033 1049.

Rindova, V.P., Pollock, T.G., Hayward, M.L.A. (2006). 'Celebrity Firms: the social construction of market popularity.' Academy of Management Review, 31(1): 50-71.

Rindova, V.P., Petkova, A.P. and Kotha, S. (2007). Standing out: How new firms in emerging markets build reputation in the media. Strategic Organization, 5(1): 31-70.

Schwaiger, M. (2004). Components and parameters of corporate reputation - an empirical study. Schmalenbach Business Review, 56: 46-71. 
Soleimani, A., Schneper, W.D. and Newburry, W. (2014). 'The Impact of Stakeholder Power on Corporate Reputation: A Cross-Country Corporate Governance Perspective', Organization Science, 25(4): 991-1008.

Stuart, H. (2002). Employee identification with the corporate identity - Issues and implications. International Studies of Management \& Organization, 32(3): 28-44.

Sturdy, A., Clark, T., Fincham, R. and Handley, K. (2009). Between innovation and legitimation-boundaries and knowledge flow in management consultancy. Organization, 16(5): $627-653$.

Suddaby, R. and Greenwood, R. (2005). Rhetorical strategies of legitimacy. Administrative Science Quarterly, 50(1): 35-67.

Suvatjis, J.Y., de Chernatony, L. and Halikias, J. (2012) Assessing the six-station corporate identity model: a polymorphic model. Journal of Product and Brand Management, 21(3): 153-166.

Tortoriello, M. and Krackhardt, D. (2010). Activating cross-boundary knowledge: the role of Simmelian ties in the generation of innovations. Academy of Management Journal, 53(1): 167-181.

Tsui, A.S. (2007). 'From homogenization to pluralism: international management research in the Academy and beyond.' Academy of Management Journal, 50(6): 1353-1364.

Verbos, A. K., Gerard, J. A., Forshey, P. R., Harding, C. S. and Miller, J. S. (2007). The positive ethical organization: Enacting a living code of ethics and ethical organizational identity. Journal of Business Ethics, 76(1): 17-33.

Verčič, A.T. and Verčič, D. (2007) Reputation as Matching Identities and Images: Extending Davies and Chun's (2002) Research on Gaps between the Internal and External Perceptions of the Corporate Brand. Journal of Marketing Communications, 13(4): 277-290

Von Nordenflycht, A. (2010). What is a professional service firm? Toward a theory and taxonomy of knowledge-intensive firms. Academy of Management Review, 35(1), 155 174.

Wade, J.B., Porac, J.F., Pollock, T.G., and Graffin, S.D. (2006). The burden of celebrity: the impact of CEO certification contests on CEO pay and performance. Academy of Management Journal, 49(4): 643-660. 
Walker, K. (2010). A systematic review of the corporate reputation literature: Definition, measurement, and theory. Corporate Reputation Review, 12(4): 357-387.

Walsh, G. and Wiedmann, K.P. (2004). A conceptualization of corporate reputation in Germany: An evaluation and extension of the RQ. Corporate Reputation Review, 6(4): 304312.

Walsh, G. and Beatty, S.E. (2007). Customer-based corporate reputation of a service firm: scale development and validation. Journal of the Academy Marketing Science, 35(1): $127-143$

Walsh, G., Mitchell, V.W., Jackson, P.R. and Beatty, S.E. (2009). Examining the antecedents and consequences of corporate reputation: a customer perspective. British Journal of Management, 20(2): 187-203.

Wartick, S.L. (2002). Measuring corporate reputation: definition and data. Business and Society, 41(4): 371-392.

Whetten, D. (1997). Theory development and the study of corporate reputation. Corporate Reputation Review, 1(1/2): 26-34.

Wilson, R. (1983). Auditing: Perspectives from multi-person decision theory. Accounting Review, 58(2): 305-318.

Yin, R.K. (2009). Case Study Research. Design and Methods ( ${ }^{\text {th }}$ edition). Sage Ltd., London. 


\section{TABLE 1: DEFINITIONS OF KEY TERMS}

\begin{tabular}{|c|c|c|}
\hline Term & Definition & References \\
\hline $\begin{array}{l}\text { Corporate } \\
\text { identity }\end{array}$ & $\begin{array}{l}\text { What the organization 'is', including its intrinsic } \\
\text { characteristics that make it unique, credible, } \\
\text { memorable, specific, coherent, and ultimately } \\
\text { supported among a broad group of stakeholders. } \\
\text { Such a strategic approach is often initiated by senior } \\
\text { managers. }\end{array}$ & $\begin{array}{l}\text { (Balmer and Greyser, 2002; } \\
\text { Cornelissen and Elving, 2003; } \\
\text { Melewar, 2003; Brown et al., } \\
\text { 2006; Balmer and Greyser, 2006; } \\
\text { Blombäck and Brunninge, 2009; } \\
\text { Kitchen et al., 2013) }\end{array}$ \\
\hline $\begin{array}{l}\text { Organisational } \\
\text { identity }\end{array}$ & $\begin{array}{l}\text { Collective shared perception, feeling, thinking and } \\
\text { understanding of an organisation's distinctive } \\
\text { characteristics and values among organisational } \\
\text { members. It emphasises what is central, enduring and } \\
\text { distinctive to an organisation or its key units of } \\
\text { analysis. }\end{array}$ & $\begin{array}{l}\text { (Albert and Whetten, 1995; Hatch } \\
\text { and Schultz, 1997, 2002; } \\
\text { Cornelissen et al., 2007; Nag et } \\
\text { al., 2007; Gioia et al., 2013; } \\
\text { Harvey et al., 2016) }\end{array}$ \\
\hline Image & $\begin{array}{l}\text { The external perception of an organisation by an } \\
\text { individual, group or collection of groups at a one-off } \\
\text { period of time based on their experiences, knowledge } \\
\text { and perceptions of the organisation. }\end{array}$ & $\begin{array}{l}\text { (Bernstein, 1984; Empson, 2001; } \\
\text { Balmer and Greyser, 2002; Hatch } \\
\text { and Scultz, 2002; Verčič and } \\
\text { Verčič, 2007) }\end{array}$ \\
\hline \multirow[t]{3}{*}{$\begin{array}{l}\text { Reputation as } \\
\text { a single lens }\end{array}$} & $\begin{array}{l}\text { The aggregated perception of an organisation by a } \\
\text { narrow stakeholder group, based on a set of } \\
\text { reputation dimensions in a finite geographic location } \\
\text { and timeframe. This is perceived as relatively stable: } \\
\text { "A relatively stable, issue specific aggregate } \\
\text { perceptual representation of a company's past } \\
\text { actions and future prospects compared against some } \\
\text { standard" (Walker, 2010, p.370). }\end{array}$ & $\begin{array}{l}\text { (Gotsi and Wilson, 2001; Barnett } \\
\text { et al., 2006; Walker, 2010; } \\
\text { Fombrun, 2012) }\end{array}$ \\
\hline & It combines into a shared, collective assessment: & \\
\hline & $\begin{array}{l}\text { "A corporate reputation is a collective assessment of } \\
\text { a company's attractiveness to a specific group of } \\
\text { stakeholders relative to a reference group of } \\
\text { companies with which the company competes for } \\
\text { resources" (Fombrun, 2012, p. 100). }\end{array}$ & \\
\hline $\begin{array}{l}\text { Reputation as } \\
\text { a prism }\end{array}$ & $\begin{array}{l}\text { The multiple, diverse and sustained perceptions of an } \\
\text { organisation, which are salient in particular ways for } \\
\text { different internal and external stakeholders, and } \\
\text { mutually exclusive. These are based on significant } \\
\text { and varied relationships and experiences of } \\
\text { stakeholders with the organisation. }\end{array}$ & $\begin{array}{l}\text { (Whetten, 1997; Ferguson et al., } \\
\text { 2000; Davies et al., 2004; Harvey } \\
\text { et al., 2016) }\end{array}$ \\
\hline
\end{tabular}


TABLE 2: CODING TABLE

\begin{tabular}{|c|c|c|c|}
\hline First order codes & $\begin{array}{l}\text { Second order } \\
\text { themes }\end{array}$ & Categories & Data sources \\
\hline $\begin{array}{l}\text { Down-to-earth } \\
\text { Realistic solutions } \\
\text { Alternative approach to other consultancies } \\
\text { Strategic thinking and implementation } \\
\text { Thought leadership in sectors } \\
\text { Restructuring work } \\
\text { Promise of tangible solutions } \\
\text { Access to extensive network } \\
\text { Corporate value of entrepreneurship }\end{array}$ & $\begin{array}{l}\text { Pragmatic } \\
\text { Creative } \\
\text { Entrepreneurial } \\
\text { Strategic }\end{array}$ & $\begin{array}{l}\text { Reputation for } \\
\text { something } \\
\text { (dimensions) }\end{array}$ & $\begin{array}{l}\text { Interviews } \\
\text { Focus groups } \\
\text { Company archives } \\
\text { Business media } \\
\text { (Factiva) } \\
\text { Non-participant } \\
\text { observations }\end{array}$ \\
\hline $\begin{array}{l}\text { Strong ties with industry and academia } \\
\text { Building competition between partners } \\
\text { Work closely with clients } \\
\text { Positive feedback from clients } \\
\text { Co-production with clients } \\
\text { Cost-cutting for clients } \\
\text { Prominent private and government projects } \\
\text { Measured outcomes and concrete results } \\
\text { Difficult to distinguish from competitors } \\
\text { Narrow focus of expertise }\end{array}$ & $\begin{array}{l}\text { Strong ties with } \\
\text { clients } \\
\text { Positive internal } \\
\text { reputation } \\
\text { Uneven reputation }\end{array}$ & $\begin{array}{l}\text { Reputation with } \\
\text { someone } \\
\text { (stakeholders) }\end{array}$ & $\begin{array}{l}\text { Interviews } \\
\text { Focus groups } \\
\text { Company archive } \\
\text { Non-participant } \\
\text { observations } \\
\text { Workshops } \\
\text { Fieldwork diary }\end{array}$ \\
\hline $\begin{array}{l}\text { Strong presence in Europe } \\
\text { Uncertain value of European identity } \\
\text { Non-American } \\
\text { Deployment of senior employees } \\
\text { Strategic mobility of talent between offices } \\
\text { Building competition between partners } \\
\text { Small presence in the UK } \\
\text { Fast growth and presence in China }\end{array}$ & $\begin{array}{l}\text { Country reputation } \\
\text { Partner and team } \\
\text { reputation } \\
\text { European }\end{array}$ & $\begin{array}{l}\text { Reputation in } \\
\text { someplace } \\
\text { (geography) }\end{array}$ & $\begin{array}{l}\text { Interviews } \\
\text { Focus groups } \\
\text { Company archives } \\
\text { Non-participant } \\
\text { observations } \\
\text { Workshops }\end{array}$ \\
\hline
\end{tabular}




\section{TABLE 3: SUPPLEMENTARY DATA SUPPORTING OUR CONSTRUCTS FOR MULTIPLE REPUTATIONS}

\begin{tabular}{|c|c|}
\hline Dimensions & Pragmatic and less creative \\
\hline \multirow[t]{4}{*}{$\begin{array}{l}\text { Reputation for } \\
\text { something }\end{array}$} & $\begin{array}{l}\text { "The strength is that the company is very much results-driven, goal-oriented" (Strategy } \\
\text { Director, Global Manufacturer, China). }\end{array}$ \\
\hline & $\begin{array}{l}\text { "They are seen as the more pragmatic consultants out there" (Head of Global } \\
\text { Conglomerate, China). }\end{array}$ \\
\hline & $\begin{array}{l}\text { "They're more practical in their approach, they're more grounded, they don't try to come } \\
\text { up with solutions that are too clever by half and will show the client up - they actually try } \\
\text { and solve the problem" (Founder and CEO of an Executive Search Firm, UK). }\end{array}$ \\
\hline & $\begin{array}{l}\text { "We are known for a hands-on approach, not being as analytical maybe such as others, } \\
\text { and being pragmatic, being out-of-the-box thinkers, not being creative" (Consultant, } \\
\text { Eastern Europe). }\end{array}$ \\
\hline \multirow{9}{*}{$\begin{array}{l}\text { Stakeholder } \\
\text { Reputation with } \\
\text { someone }\end{array}$} & Senior-level positions \\
\hline & $\begin{array}{l}\text { "That's certainly something that's come across quite clearly from a lot of people, that the } \\
\text { quality of [Novel Insights] work is very much down-to-earth, about implementation, } \\
\text { pragmatic" (Managing Partner of Novel Insights, UK). }\end{array}$ \\
\hline & $\begin{array}{l}\text { "[Novel Insights] is much more into implementing projects, being a coach and a partner } \\
\text { for the client and helping the client" (Founder and CEO of a specialist consulting firm, } \\
\text { Germany). }\end{array}$ \\
\hline & Middle-level positions \\
\hline & $\begin{array}{l}\text { "We stand for close cooperation with clients, tailor made. We don't copy and paste" } \\
\text { (Project Manager of Novel Insights, Eastern Europe). }\end{array}$ \\
\hline & $\begin{array}{l}\text { "But the weakness would probably be I think that, in terms of the strategic level, and also } \\
\text { professional level, I think that [... Novel Insights] is still lower than, you know, some } \\
\text { other international brands" (Director of a Global Manufacturer, China). }\end{array}$ \\
\hline & Junior-level positions \\
\hline & $\begin{array}{l}\text { "I don't think that, at least among my friends from university, we had a very strong } \\
\text { reputation for being the most strategic, the most creative, the most diversified consultancy } \\
\text { firm. I don't think we do. We have a more straightforward, concrete, operational } \\
\text { reputation" (Junior Consultant of Novel Insights, Austria). }\end{array}$ \\
\hline & $\begin{array}{l}\text { "I would say, from my experiences, it's the restructuring that sort of was what the } \\
\text { company was founded on, and it's what we are still recognised today as being a strong } \\
\text { restructuring focused company" (Consultant of Novel Insights, UK). }\end{array}$ \\
\hline \multirow{6}{*}{$\begin{array}{l}\text { Geography } \\
\text { Reputation in } \\
\text { someplace }\end{array}$} & China \\
\hline & $\begin{array}{l}\text { "So if I give my business card to someone, it will range from, "[Novel Insights], what?" to } \\
\text { "Oh, I know this company - this is a good company." Of course, sometimes people don't } \\
\text { say, you know, they don't like it, but the range is very broad, okay, of reaction when you } \\
\text { issue the card, which is a bit sometimes annoying because the range is too broad" (Partner } \\
\text { of Novel Insights, China). }\end{array}$ \\
\hline & $\begin{array}{l}\text { "We are not so aggressive like other American consulting firms. We are down-to-earth. } \\
\text { We like to know what clients really want and will deliver according to their exact needs, } \\
\text { and so that we win a lot of local clients in even the second and third tier Chinese cities" } \\
\text { (Consultant of Novel Insights, China). }\end{array}$ \\
\hline & UK \\
\hline & $\begin{array}{l}\text { "I think we are strong in achieving change, so engaging with people. That's because we } \\
\text { work alongside management, so we support management. So I think we are strong in } \\
\text { building up trust and giving confidence, managing difficult situations, and in really } \\
\text { becoming a partner" (Partner of Novel Insights, UK). }\end{array}$ \\
\hline & $\begin{array}{l}\text { "My conception of their reputation was that they were an international firm, but more } \\
\text { focused in Europe and in Asia than in the US" (Senior Consultant of Novel Insights, UK). }\end{array}$ \\
\hline
\end{tabular}




\section{FIGURE 1: REPUTATION AS A PRISM}

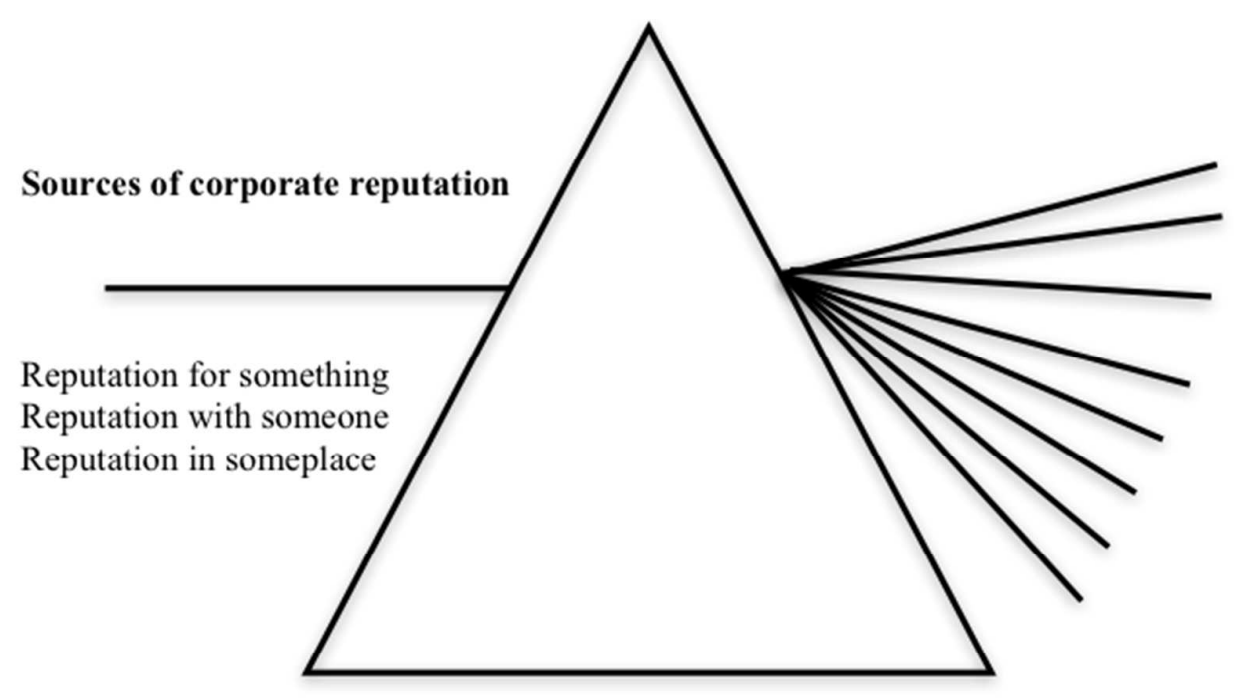

 